\title{
The impact of the 2007 reforms in China on the quality of earnings
}

\author{
Siming Liu* \\ Len Skerratt \\ Shaomeng Li
}

This version: June 2015

*Corresponding author: Siming.Liu@ brunel.ac.uk

Siming Liu is Lecturer in Accounting and Finance, Department of Economics and Finance, Brunel University.

Len Skerratt is Visiting Professor, Brunel Business School.

Shaomeng $\mathrm{Li}$ is a postdoctoral $\mathrm{PhD}$ in the Department of Economics and Finance, Brunel University.

We are grateful to William Forbes, Jill Collis and participants of a seminar given at Brunel Business School for helpful comments on an earlier draft. 


\title{
The impact of the 2007 reforms in China on the quality of earnings
}

\begin{abstract}
Prior to 2007, in order to encourage international investment, China operated two parallel financial reporting systems, one based on Chinese GAAP for domestic investors and the other based on IFRS for international investors. In 2007 after a series of reforms to harmonise Chinese GAAP with IFRS, this system was replaced by a single set of standards for both classes of investor. We evaluate the impact of this significant change on earnings quality for stocks quoted on the Shanghai and Shenzhen stock exchanges for the period 2003-2013. Using tests of earnings smoothing and early loss recognition, we identify three key features. Firstly, earnings quality improved consistently over the period. Secondly, prior to the reforms of 2007, IFRS earnings were of superior quality to Chinese GAAP earnings. A third and important finding is that earnings quality under Chinese GAAP after the 2007 reforms is comparable to that under pre-2007 IFRS.
\end{abstract}

148 words

Keywords: Earnings Quality, IFRS and Chinese GAAP convergence, and Accounting Reform 


\section{The impact of the 2007 reforms in China on the quality of earnings}

\section{Introduction}

As part of its transition to a market oriented economy, China introduced a number of accounting reforms. Initially, there was a dual reporting system. International investors received financial reports based on IFRS whilst reports to domestic investors used Chinese GAAP, a less demanding set of standards, although also still based on Western reporting practices. In 2007, there was an important change. Chinese GAAP was significantly upgraded to reflect IFRS and this set of standards was mandatory for reporting to both domestic and international investors.

The impact of these 2007 reforms is relatively under researched, particularly the actual effect on earnings quality, rather than the beliefs of investors about it. In this paper, we investigate the consequences of the reforms by investigating earnings quality of companies quoted on the Shanghai and Shenzhen stock exchanges over the period 2003-2013. We focus on earnings smoothing and timely loss recognition, two key features of earnings quality. Our results show clearly that overall earnings quality improved steadily throughout the period, although prior to 2007 IFRS earnings were superior to those based on Chinese GAAP. However, companies appear to have responded well to the 2007 reforms such that the quality of Chinese GAAP earnings is now similar to that of pre-2007 IFRS earnings.

Our paper is structured as follows. First there are sections explaining, in more detail, the background to the study and the contribution of the paper. Then follows sections 
on our methodology and sample selection. We conclude with an analysis of the results, some additional tests and a summary of our findings.

\section{Background and prior literature}

\subsection{Early harmonisation reforms prior to 2007}

One of the first harmonisation reforms was Enterprise Basic Accounting Standards introduced in 1993 along with changes in the national accounting law to commence the harmonisation process towards accounting standards adopted in the developed world. Subsequent reforms, with a view to harmonisation with IFRS, were Accounting System for Joint Stock Limited Enterprises in 1998 and Accounting System for Business Enterprises in 2001. These changes were accompanied by significant amendments to the corporate ownership structure, corporate governance and market infrastructure. Chinese listed companies were able to issue several classes of share: A shares, for domestic investors, although only about one third of these could be traded; B shares for international investors; and $\mathrm{H}(\mathrm{N})$ shares for those companies also quoted on the Hong Kong (New York) stock market. Moreover, different classes of shareholder received different financial statements. Investors holding A shares received statements prepared in accordance with Chinese domestic standards (Chinese GAAP), whilst investors holding B shares received statements prepared under IFRS (Wu, Li, Lin, 2014).

These changes in accounting regulation towards harmonisation with IFRS are examined in a number of studies. The evidence concerning China's progress towards developed world accounting standards is somewhat fragmentary, but overall there seems to have been some initial caution over IFRS earnings since Eccher and Healy 
(2000) and $\mathrm{Hu}$ (2002) found that Chinese GAAP earnings are more strongly associated with stock prices. However, this scepticism about IFRS seems misplaced since Eccher and Healy (2000) also find that Chinese GAAP earnings are no better than IFRS earnings at predicting future cash flow. Subsequent studies suggest that the stock market became more accustomed to working with IFRS since later studies such as Sami and Zhou (2004) and Liu and Liu (2007) find that IFRS earnings are more informative of stock prices than Chinese GAAP earnings.

Other studies focus on more specific issues. Corporate governance structures do not seem to have influenced the harmonisation of Chinese GAAP to IFRS (Chen and Cheng 2007), although shareholders tend to pay a price premium where corporate governance is effective (Bai, Liu, Lu, Song and Zhang 2003). There is some evidence that audit quality reduces earnings management (Chen, Chen, Lobo, and Wang 2010). Liu, Saidi, and Bazaz (2014) report that companies with significant state control have poorer quality earnings.

The impact of the early reforms in progressing China towards developed economy accounting practices is difficult to gauge because each of the studies uses a pooled sample with no time dimension. In addition, the sample periods covered by the studies are overlapping and therefore it is difficult to obtain any precise idea of progress. A second complication is the comparisons which some of the studies make between Chinese GAAP and IFRS earnings of Chinese companies. It is difficult to interpret these comparisons since the international standards used are only a partial reflection of the IFRS practices implemented in the West (Deloitte, 2005). Consequently, at this stage, perhaps IFRS earnings number is not an appropriate benchmark to assess Chinese GAAP earnings. A third reason for caution is that a number of studies do not evaluate the quality of earnings directly, but use stock prices as a proxy. They 
measure how much weight stock prices give to earnings. The assumption here is that the market is rational and well informed, which in a transition economy may not be the case.

\subsection{The 2007 IFRS convergence reforms}

In 2006, the Chinese Ministry of Finance announced the convergence of Chinese accounting standards with IFRS by issuing a revised version of Accounting Standards for Business Enterprises. It specified that from 1 January 2007, the standards were to be mandatory for all companies listed on Chinese stock exchanges; and significantly, financial statements for both class A and class B shareholders were to be prepared under the revised Chinese GAAP (Wu, Li, Lin, 2014). This was an important and bold step in China's transition, bringing companies with domestic investors in to line with those companies already accustomed to reporting to its international investors through standards based on IFRS.

Given the significance of this convergence to IFRS for all companies, a number of studies have tried to assess its impact on the quality of reported earnings. Qu, Fong and Oliver (2012) report that for A shares, stock prices in 2008-10 period give greater weight to earnings than in the 2004-6 period. This suggests that at least the stock market had increased confidence in the convergence to IFRS. However, some reservations are relevant. As mentioned above, the method is only indirect evidence that the reforms improved earnings quality since the method captures the beliefs of the market, which may not always be based on economic reality. In addition, the study also finds a counter-intuitive result that book value has a negative influence on stock prices in the 2008-2010 period. 
The study by $\mathrm{Wu}, \mathrm{Li}$ and Lin (2014) also adopts a market based approach, but has some surprising results. The weight given to current earnings in the valuation of stocks in the 2007-9 period is significant, but not any larger than the weight given to either Chinese GAAP or IFRS earnings in the pre-harmonisation period 1994-97. In addition, earnings seem to be given no weight in the harmonisation period (19982005), in contrast to other studies such as $\mathrm{Hu}$ (2002) and Sami and Zhou (2004). A main contention of the research is that the timeliness of earnings has worsened. They find that, uniquely in the IFRS convergence period 2007-2009, stock returns are related to earnings in the following period. This suggests that information which is reflected in stock prices in one period is not reflected in earnings until the following period. This means that earnings are slow at capturing information which is relevant for stock prices. However, the finding may simply be a sign of increased stock market efficiency. It is a common finding that prices in a well-functioning stock market reflect future information (Weiss, Naik, and Tsai 2008), and perhaps this aspect of the Chinese markets improved in IFRS convergence period.

A direct test of earnings quality is reported in a study by Kao (2014) which estimates earnings management over the $2002-9$ period. It reports results for the pooled sample, and therefore its results cannot indicate what changes have occurred between the pre and post convergence periods. An analysis of the impact of the reforms on earnings quality is given by Liu, Yao, Hu, and Liu (2011). They compare the 2007-8 post reform period with 2005-6. They report an improvement in earnings quality in that the smoothness of earnings decreased. However, they report no significance tests of whether this is due to less smoothing activity or to a greater volatility of the underlying cash flows. They also report, using the Basu (1997) test of timely loss recognition, that there was no early recognition of future losses in either period. 
However, this may not be an appropriate test in a developing economy. The test compares earnings with stock returns; the underlying intuition is that whilst returns capture both future profits and losses, the conservatism principle means that earnings captures only future losses. Thus there should be a closer link between earnings and stock prices when both are anticipating future losses. A weakness of the test, particularly for our purposes, is that it assumes that the existence of future losses is adequately proxied by negative current stock returns. However, in a transitioneconomy stock market, prices may not adequately reflect information about the future. Furthermore, the assumption may be problematic even in a well developed market. Negative returns are not caused only by expected future losses, and losses are not always associated with prior negative returns.

\section{Contribution of the study}

\section{$\underline{3.1 \text { A recent sample }}$}

Changes in financial regulation may need some time to be reflected in company practice. Therefore the short run consequences may be very different from those in the medium term. In this respect it is important to have up to date evidence, particularly when prior work indicates that the policy change has improved practice only marginally at best; smoothing behaviour appears to have improved only slightly and the timely loss recognition is reported to be actually poorer.

The studies which examine the market weighting given to earnings are $\mathrm{Qu}$, Fong, and Oliver (2012) who study 309 companies for 2008-10 and $\mathrm{Wu}, \mathrm{Li}$, and $\mathrm{Lin}$ (2014) analyse only 84 companies over the $2007-9$ period. As mentioned above, this evidence is somewhat imperfect since it is a view through the eyes of market prices. 
The study which is closest to ours is Liu, Yao, Hu and Liu (2011) which reports direct tests of earnings quality. They cover 870 companies during 2007-8. Our tests cover the period 2003-2013, and therefore extend the post reform period time frame significantly to 2007-2013, whilst covering a comparable number (744) of companies.

\subsection{Direct tests of earnings quality}

The 2007 reforms of accounting and reporting regulation were a major step in aligning China's economy with the developed nations. The reforms promulgated a single set of standards for all companies, whether they have international investors or not. How Chinese companies have faced up to this challenge has received attention in only a few studies. Furthermore, the assessments are largely indirect, through the weight placed on earnings in the valuation of stocks. As we argue above, this approach places too much emphasis on the market's evaluation at a time when its own infrastructure (such as the expertise and understanding of market analysts) is also undergoing significant change. In view of this possibility, our tests are a direct test of the quality of earnings. These are discussed next.

\subsection{Smoothness tests}

The smoothing of earnings is an important objective for companies trying to show their performance in a favourable light. But the drawback for investors is that smoothing hides company risk. Therefore, the lack of smoothness is a key component of earnings quality, particularly since it contextualises any earnings management by capturing the impact on the level of earnings. A weakness of the smoothing tests conducted in Liu, Yao, Hu, and Liu (2011) is that they are incomplete. They show (their Table 2) that the smoothness of earnings significantly decreased in the post reform period. However, in their significance tests, they do not benchmark the volatility of earnings against the underlying volatility of cash flows; more volatile 
earnings may be due to less smoothing activity or a greater volatility of the underlying cash flows. We conduct the same smoothing tests, but perform significance tests with a bootstrap procedure.

\subsection{Timely recognition of bad news}

An important aspect of earnings quality is its conservatism, in alerting investors to potential liabilities and bad news in the future. Both Liu, Yao, Hu, and Liu (2011) and Wu, Li, and Lin (2014) report a lack of timeliness in earnings. Both studies use stock returns as the benchmark, which are assumed to adequately reflect future cash performance. Liu, Yao, Hu, and Liu (2011) find that in the post-reform period in contrast to the prior period, some information which is impounded in stock prices is not captured by earnings until the next period. However, as mentioned above, this is a well established property of stock prices in developed economies (see for example Kothari and Sloan 1992, and Weiss, Naik, and Tsai, 2008); the explanation for the finding may be the increased efficiency of the market, rather than a decline in the timeliness of earnings. $\mathrm{Wu}, \mathrm{Li}$, and Lin (2014) find that, in the post-reform period, bad news tends not to be anticipated by earnings. However, as mentioned above, the test which they use assumes that negative stock returns adequately capture future bad news, an assumption which is questionable even in fully perfectly efficient stock market. Therefore, we conduct a direct test of timely recognition of economic losses devised by Ball and Shivakumar (2005), based on the speed with which earnings bounce back after a decline in earnings; the faster that earnings bounce back the more likely it is that the current decline also captures future bad news. 


\section{Methodology}

\subsection{The conditional conservatisms of earnings}

Our first earnings quality measure is conditional conservatism, which is a time series measure of earnings conservatism. We perform this test across sample period of 20032013, in order to examine the changes in conservatism over time. To measure conditional conservatism, we adopt the model outlined in Ball and Shivakumar (2005), which are widely used in various research papers such as Givoly, Hayn and Katz (2010), and Hope Thomas and Vyas (2013). The model is as follows.

$\Delta N I_{i, t}=\alpha_{0}+\alpha_{1} D \Delta N I_{i, t-1}+\alpha_{2} \Delta N I_{i, t-1}+\alpha_{3} D \Delta N I_{i, t-1} \times \Delta N I_{i, t-1}+\alpha_{4}$ Size $_{i, t}+$ $\alpha_{5}$ Industry Dummies Dut $_{t}+\varepsilon_{t}$

where: $\Delta N I_{i, t}$ is the change in income from year $t-1$ to $\mathrm{t}$, scaled by total assets; $D \Delta N I_{i, t-1}$ is a dummy variable equal to 1 if $\Delta N I_{i, t-1}$ is negative; Size $e_{i, t}$ is the control variable to control for size differences between firms, which is the natural logarithm of total assets; Industry Dummies Dit $_{\text {in }}$ is the interactive control variables to control for industry differences; $i$ takes values from $1, \ldots, n_{t}$; and $t$ takes values from 2003, $2004, \ldots, 2013$. The intuition underlying the test is that negative changes in earnings revert quicker than positive changes because bad news is more fully recognized in income; this means that economic losses are recognised in a timelier manner than gains. Therefore, $\alpha_{3}$ is expected to be negative.

\subsection{The smoothness of earnings}

Our second measure of accounting quality is a general one, capturing the smoothing of earnings and is based on Lang, Raedy and Yetman (2003) and Barth, Landsman and Lang (2008) who compare the quality of reporting across IAS and non-IAS regimes. The smoothness of earnings is a firm- specific time series concept. However, there are drawbacks to measuring smoothness at the firm level, primarily the selection 
bias arising from the need to obtain a sufficient number of observations and the implied stability of the coefficients over time. Instead our approach is to include a time dimension by examining the change in earnings, which is then set in the context of other companies in a cross section, controlling for extraneous variables following Lang, Raedy and Yetman (2003) and Barth, Landsman and Lang (2008). It is also used in the study of the 2007 reforms of Chinese financial reporting by Liu, Yao, $\mathrm{Hu}$ and Liu (2011).

The first step to test for the smoothness of earnings is to mitigate the effect of the economic factors which may influence smoothness of earnings by regressing the change in earnings scaled by total assets on a number of control variables. The variance of the residuals from this regression $[V(\Delta N I)]$ is then used as an estimate of the smoothness of earnings. A smaller $V(\Delta N I)$ is an indication of earnings smoothness. Specifically, we run the following regression for each group to examine earnings smoothness. $\Delta N_{i, t}=\alpha_{0}+\alpha_{1}$ Size $_{i, t}+\alpha_{2}$ Growth $_{i, t}+\alpha_{3}$ Lev $_{i, t}+\alpha_{4}$ Dissue $_{i, t}+\alpha_{5}$ Turn $_{i, t}+$
$\alpha_{6}$ CF $_{i, t}+\alpha_{5}$ Industry Dummies $_{i, t}+v_{i, t}$

where: $\Delta N I_{i, t}$ is the change in earnings scaled by total assets; $S i z e_{i, t}$ is the natural logarithm of end of year value of equity; rrowth $_{i, t}$ is the proportionate change in sales; $L e v_{i, t}$ is the end of year total liabilities divided by end of year equity book value; Dissue $_{i, t}$ is the percentage change in total liabilities; Turn $_{i, t}$ is sales divided by end of year total assets; and $C F_{i, t}$ is the cash flow from operating activities divided by end of year total assets; Industry Dummies Dit, $_{\text {is }}$ the interactive control variables to control for industry differences. $i$ takes values from $1, \ldots, n_{t}$; and $t$ takes values from 2003, 2004, .., 2013. 
A weakness of $V(\Delta N I)$ is the way in which it controls for the economic factors which may affect the smoothness of earnings. Although the variables are firm specific, the coefficients of the model are estimated across the entire sample. This procedure is therefore unlikely to eliminate all of the firm specific economic components of smoothness which operate at the firm level; consequently, the regression residual is likely to contain both firm specific economic as well as accounting factors which affect smoothness.

Our test for smoothness attempts to mitigate this confounding of economic and accounting factors, and is again based on Lang, Raedy and Yetman (2003) and Barth Landsman and Lang (2008). We compare the smoothness of the change in earnings, $V(\Delta N I)$ from equation (2), with the smoothness of the change in cash flow from operations, which is estimated in a similar way to the smoothness of earnings equation, but with $\triangle C F$ as the dependent variable, as follows.

$\Delta C F_{i, t}=\alpha_{0}+\alpha_{1}$ Size $_{i, t}+\alpha_{2}$ Growth $_{i, t}+\alpha_{3}$ Lev $_{i, t}+\alpha_{4}$ Dissue $_{i, t}+\alpha_{5}$ Turn $_{i, t}+$ $\alpha_{6} C F_{i, t}+\alpha_{5}$ Industry Dummies Di,t $+v_{i, t}$

where: $\Delta C F_{i, t}$ is the change in cash flows from operations scaled by total assets. We obtain the variance of residual from equation $4,[V(\Delta C F)]$, as the smoothness of cash flows from operation. The term $V(\Delta C F)$, like $V(\Delta N I)$, will contain the firm specific economic components of cash flow smoothness since the parameter values are estimated across the sample; however, $V(\triangle C F)$ is less likely to contain accounting components of earnings smoothing ${ }^{1}$. Taking the ratio of $V(\Delta N I) / V(\Delta C F)$ attempts to scale out the firm specific economic components of earnings smoothing leaving those

\footnotetext{
${ }^{1}$ However, to the extent that the control variables are inadequately measured by the accounting system, $V(\triangle C F)$ may also contain accounting factors.
} 
that relate to accounting methods. A smaller ratio is an indication of earnings smoothness.

Equation (2) and (3) are used to test the earnings smoothness over time period of 2003-2013. In order to compare the differences in earnings variability between each year as well as each type of firms, following Barth et al (2008), we estimate the standard error of the ratio, $V(\Delta N I) / V(\triangle C F)$ by a bootstrap procedure as follows. From the original sample, we randomly select (with replacement) a new sample of the same size, and estimate equations 2 and 3 again to obtain $V(\triangle N I) / V(\triangle C F)$; this procedure is repeated 1000 times to obtain the estimated sampling distribution and hence the standard error. The mean and standard deviation of each distribution are reported in the tables ${ }^{2}$ for comparison.

\section{Sample and Data}

The purpose of this paper is to examine the relationship between financial reporting standards and earnings quality under Chinese accounting systems, and to further analyse the changes of earnings quality in relation to changes in accounting standards over the period of 2003-2013, which includes the major reforms in Chinese accounting systems.

We matched the databases of Datastream and Thomson Reuters based on accounting information and obtained observations that have available accounting and market data between 2003 and 2013. The sample consists of all Chinese-listed firms that issue Aand B- shares on the Shanghai Stock Exchange and Shenzhen Stock Exchange. We exclude companies with qualified accounts during the observation period, because

\footnotetext{
${ }^{2}$ We also report the statistics for $V(\Delta N I)$ which are constructed in a similar way.
} 
firms with qualified accounts are likely to be different from typical observation in terms of financial measures and reporting incentives. A total of 744 sample firms that are examined are from different industries as shown in Table 1. The resulting sample includes 8,184 firm-year observations from different industries ${ }^{3}$. We observe that almost half of firms are from manufacturing industry.

Table 1 here

\section{Analysis of results}

\subsection{Descriptive Statistics}

Table 2 gives the summary statistics of the accounting variables used in the study, which reflect the main variables used to construct our earnings quality measure. As the variables based on measure of earnings quality are sensitive to outliers, all nondummy variables are winsorized at 5\% level following Ball and Shivakumar (2005) and Barth et al. (2008). We observe that, changes in earnings and changes in cash flows are more varied after the year of 2007. Although these two variables are not controlled for other factors, they suggest that firms after 2007 are unlikely to have a higher level of earnings smoothness. Chinese listed firms have high leverage, indicating that they have a greater reliance on debt to fund or finance the business. In addition, sales and total debts issued for Chinese firms have been increasing over time. Next, we analyse our multivariate regression test results.

Table 2 here

\footnotetext{
${ }^{3}$ We also need prior year data (2002-2013) to calculate changes in earnings and lagged total assets, but this is not part of our sample period for the tests.
} 


\subsection{Conditional conservatism of earnings}

Table 3 presents the results on conservatism from estimating the equation (1) across individual year from 2003-2013. Our predictions concerning conditional conservatism are based on Ball and Shivakumar (2005), that economic losses receive timelier recognition than gains, that we expect $\alpha_{3}$ to be negative. Overall Chinese listed firms present a conservative nature as $\alpha_{3}$ is negative across all years, suggesting that Chinese listed firms do recognise the losses in a timely manner. The level of conservatism appears to vary during the pre-reform period, in that $\alpha_{3}$ is highest (0.230) in 2003, becomes non-significant in 2005 and rises again (-0.189) in 2006. Such variations in conservatism perhaps reflect the uneven application of Chinese GAAP during the period. However, the level of conservatism has increased systematically during the post reform period, from -0.283 in 2008 to -0.378 in 2013 , indicating that earnings quality has improved after the convergence of Chinese GAAP with IFRS.

Table 3 here

\subsection{The smoothness of earnings}

Table 4 presents the smoothness of earnings test for each individual year, for the sample period 2003-2013. According to Lang et al (2006) and Barth et al (2008), a smaller variance of residual $[V(\Delta N I)]$ and a smaller ratio $[V(\Delta N I) / V(\Delta C F)]$ are an indication of earnings smoothness. For the $V(\Delta N I)$ measure, the level of smoothness is lower during pre-reform period than that in post reform period, suggesting that firms smoothed their earnings more during the pre-reform period. Furthermore, the level of smoothness fluctuates before 2007, with 2005 having the lowest $V(\Delta N I)$. 
After mitigating for firm specific factors by taking the ratio of earnings variability to cash flows variability, $V(\Delta N I) / V(\Delta C F)$, the results show much the same picture. In particular, the ratio values for 2012 and 2013 (0.6725 and 0.7747 respectively) are much larger than in the pre-reform period. Therefore, the results for the smoothness of earnings across different sample years yield similar findings to the conservatism test; firms smooth their earnings less during the post reform period than in the pre-reform period.

Table 4 here

\section{Additional Analyses}

We find above that earnings quality has varied during the pre-reform period. This could be due to the differential accounting standards applied by different classes of company. Before the reform of accounting standards in 2007, financial statements for investors holding A shares were prepared in accordance with Chinese GAAP, whilst for those holding B shares were prepared under IFRS (Wu et al 2014). In order to further analyse the impacts of accounting standards on earnings quality, we perform our conservatism and smoothing tests distinguishing between firms which follow IFRS and Chinese GAAP during the sample period.

\subsection{The conditional conservatisms of earnings}

We estimate equation (4), which is modified based on equation (1) to allow differences between Chinese GAAP firms and IFRS firm. We test the incremental differential persistence between IFRS firms and GAAP firms by including additional dummy variable $\operatorname{DIFRS} S_{i, t}$, which takes the value 1 for IFRS firms and 0 for GAAP 
firms. The modified regression that allows differences between IFRS and GAAP firms is estimated as follows:

$$
\begin{aligned}
\Delta N I_{i, t}=\alpha_{0}+ & \alpha_{1} D \Delta N I_{i, t-1}+\alpha_{2} \Delta N I_{i, t-1}+\alpha_{3} D \Delta N I_{i, t-1} \times \Delta N I_{i, t-1}+\alpha_{4} D_{I F R S_{i, t}} \\
& +\alpha_{5} D I F R S_{i, t} \times D \Delta N I_{i, t-1}+\alpha_{6} D I F R S_{i, t} \times \Delta N I_{i, t-1}+\alpha_{7} D I_{F R S_{i, t}} \\
& \times D \Delta N I_{i, t-1} \times \Delta N I_{i, t-1}+\alpha_{8} \text { Size }_{i, t}+\alpha_{9} \text { Industry Dummies }_{i, t}+\varepsilon_{t}
\end{aligned}
$$

where $\operatorname{DIFRS}_{i, t}$ is a dummy variable that takes the value 1 for IFRS firms and 0 for GAAP firms, and other variables are as defined above. We expect that economic losses receive timelier recognition than gains, and if firms follow IFRS, they are more likely to recognize economic losses in a timely fashion than firms which follow Chinese GAAP; hence, the coefficient $\left(\alpha_{7}\right)$ on IFRS firms is expected to be negative.

\section{Table 5 here}

The result of this test is presented in Table 5. It shows that firms do recognise the losses in a timelier manner across all the three sample periods in that the $\alpha_{3}$ coefficient is significantly negative throughout. It becomes more negative in the postreform period $(-0.389)$ compared to the pre-reform period $(-0.201)$, which is consistent with our previous conservatism tests on individual years. The effect of IFRS during the pre-reform period can be seen in the value of $\alpha_{7}$ which is negative (0.195) suggesting that the earnings for firms following IFRS are more conservative than firms following Chinese GAAP. In contrast, the value of $\alpha_{7}$ is not significant in the post-reform period, suggesting that the level of conservatism for firms following Chinese GAAP is similar to those following IFRS ${ }^{4}$. The 2007 reforms appear to have

\footnotetext{
${ }^{4}$ Strictly, no company should be following IFRS in the post-reform period; all companies should be following Chinese GAAP which had converged with IFRS. However, a minority of companies still report that they apply IFRS.
} 
been successful in raising Chinese GAAP to an IFRS level. This indication is corroborated by the fact that $\alpha_{3}+\alpha_{7}$ in the pre-reform period $[(-0.201)+(-0.195)]$ is very similar to the level of $\alpha_{3}$ in post-reform period (-0.389), implying that the level of conservatism for GAAP-firms in post-reform period is similar to the level of conservatism of IFRS-firms in the pre-reform period. Overall, the level of conservatism for Chinese listed firms appears to have improved since the convergence of Chinese GAAP to IFRS in 2007.

\subsection{The smoothness of earnings}

We re-ran equations (2) and (3) after dividing the sample into firms which follow IFRS and Chinese GAAP during pre and post-reform periods to further examine the difference in earnings quality for IFRS and Chinese GAAP firms. The differences in earnings quality are examined by bootstrapping the variance of residuals to obtain empirical distributions, and the standard errors for each empirical distribution are used for comparison.

Table 6 here

The results of these tests are tabulated in Table 6. Firms which follow Chinese GAAP appear to have more earnings smoothing, that is lower $V(\Delta N I)$ and $V(\Delta N I) / V(\Delta C F)$, in the pre-reform period compared to the post-reform period; for example, $V(\Delta N I) /$ $V(\triangle C F)$ is 0.5882 in the pre-reform period compared with 0.6939 in the post-reform period. These differences are statistically significant, and suggest that earnings quality for firms following Chinese GAAP has significantly improved after the 2007 accounting reform. Furthermore, the Chinese GAAP firms in the post-reform period have similar level of smoothness to IFRS firms in the pre-reform period. The 
$V(\Delta N I) / V(\triangle C F)$ measure is 0.6939 in the post-reform period for Chinese GAAP firms and 0.6825 for IFRS firms in the pre-reform period. This suggests that earnings quality under local standards converged with IFRS, which is consistent with the previous loss recognition tests in Table 5.

In contrast, the firms which follow IFRS in the post-reform period appear to have smoother earnings than in the pre-reform period; for example, $V(\Delta N I) / V(\triangle C F)$ is 0.5970 in the post-reform period, but 0.6825 in the prior period. This may be due to the small number of firm-year observations. However, following 2007, firms are supposed to follow Chinese GAAP which is converged with IFRS; therefore the lower values of $V(\Delta N I)$ and $V(\Delta N I) / V(\Delta C F)$ may be an indication of firms managing earnings for a specific purpose.

\section{Summary and Conclusions}

Prior to 2007, in order to encourage international investment, China operated two parallel financial reporting systems, one based on Chinese GAAP for domestic investors and the other based on IFRS for international investors. In 2006, China issued revised accounting standards to converge with IFRS, and all companies listed on Chinese stock exchanges were required to prepare financial statements under the revised Chinese GAAP, which is effective from 1 January 2007. The convergence of Chinese GAAP and IFRS has been studied by relatively few papers. Moreover, even fewer conduct direct tests of accounting quality; instead they evaluate the quality of earnings using stock prices as a proxy benchmark, with the assumption that the market is rational and well-informed, which may not be the case in a transitional economy. 
The purpose of this paper is to examine the impact of 2007 accounting reform on earnings quality. We measure earnings quality by earnings smoothness and timely loss recognition, which are two direct tests on earnings quality. Earnings smoothness contextualises any earnings management by capturing its impact on the level of earnings, while timely loss recognition tests the speed with which earnings bounce back after a decline in earnings; the quicker earnings bounces back, the more likely it is that declines in future performance have been anticipated and impounded in current earnings.

We first explore the changes in earnings quality for Chinese listed firms over time, and our results indicate that the accounting quality for Chinese listed firms has improved over the 2003-2013 period. We analyse the differences in earnings quality for firms following Chinese GAAP and IFRS in both pre and post-reform periods. We find that prior to the reforms of 2007, IFRS earnings were of superior quality to Chinese GAAP earnings. We also find that the 2007 reforms have improved earnings quality and that Chinese GAAP is now comparable to pre-2007 IFRS.

This paper highlights the issue of convergence of Chinese GAAP with IFRS on earnings quality. Generally, our evidence suggests that the earnings quality for Chinese listed firms has improved over time and the convergence of Chinese GAAP with IFRS has also resulted in improved earnings quality. The findings of this paper shed light on developments in accounting standards and highlight the benefits brought by IFRS for decision-making and interpretation concerning financial reports. 


\section{References}

Bai, C., Q. Liu, J. Lu, F. Song, and J. Zhang. 2003. "Corporate governance and market valuation in China." Available at: http://ssrn.com/abstract=393440, accessed 4 June 2015.

Ball, R., and L. Shivakumar. (2005). "Earnings quality in UK private firms: comparative loss recognition timeliness." Journal of Accounting and Economics 39: 83-128.

Bao, B., and L. Chow. 1999. "The usefulness of earnings and book values for equity valuation in emerging capital markets: evidence from listed companies in the People's Republic of China." Journal of International Financial Management and Accounting 10: 85-104.

Basu, S. 1997. "The conservatism principle and the asymmetric timeliness of earnings." Journal of Accounting and Economics 24: 3-37.

Chan, A., R. Ding, and W. Hou. "Does mutual fund ownership affect financial reporting quality for Chinese privately owned enterprises?" International Review of Financial Analysis forthcoming. Available at: http://ssrn.com/abstract=2264073, accessed 4 June 2015.

Chen, H., J. Chen, G. Lobo, and Y. Wang. 2010. "Effects of audit quality on earnings management and cost of equity capital: evidence from China." Available at: http://ssrn.com/abstract=1105539, accessed 4 June 2015.

Chen, J., and P. Cheng. 2007. "Corporate governance and harmonisation of Chinese accounting practices with IFRS practices." Corporate Governance 15(2):284-293.

Chen, K., and H. Yuan. 2001.'Earnings management and capital resource allocation: evidence from China's accounting based regulation of rights issues." Available at: http://ssrn.com/abstract=245067, accessed 4 June 2015.

Deloitte. 2005. "Comparison between PRC_GAAP and IFRS." Deloitte Touche Tohmatsu, 29 pages.

Eccher, E., and P. Healy. 2000. "The role of international accounting standards in transitional economies: a study of the People's Republic of China." Available at: http://ssrn.com/abstract=233598, accessed 4June2015

Hu, D. 2002. "The usefulness of financial statements under Chinese GAAP vs IAS: evidence from the Shanghai Stock Exchange in PRC." SSRN 314001.

Kao, H. 2014.'The relationship between IFRS, earnings losses threshold and earnings management." Journal of Chinese Economic and Business Studies 12(1): 81-98. 
Kothari, S., and R. Sloan. 1992. "Information in prices about future earnings: implications for earnings response coefficients." Journal of Accounting and Economics 15: 143-171.

Lai, L. 2009. "Managing earnings to meet critical thresholds and the role of corporate governance: a case study of China." Available at: http://ssrn.com/abstract=1326191, accessed 4 June 2015.

Liu, C., L. Yao, N. Hu, L. Liu. (2011). "The Impact of IFRS on Accounting Quality in a Regulated Market: An Empirical Study of China." Journal of Accounting, Auditing \& Finance 26(4): 659-676.

Liu, J., and C. Liu. 2007. "Value relevance of accounting information in different stock market segments: the case of Chinese A-, B- and H-shares." Journal of International Accounting Research 6 (2): 55-81.

Liu, X., R. Saidi, and M. Bazaz. 2014. "Institutional incentives and earnings quality: the influence of government ownership in China." Journal of Contemporary Accounting and Economics 10: 248-261.

McGee, R., and X. Yuan. 2008. "Corporate governance and the timeliness of financial reporting: an empirical study of the People's Republic of China." Available at: http://ssrn.com/abstract=1131338, accessed 4June2015

Qu, W., M. Fong, and J. Oliver. 2012. "Does IFRS convergence improve quality of the accounting information? Evidence from the Chinese stock market." Corporate Ownership \& Control 9(4): 187-196.

Sami, H., and H. Zhou. 2004. "A comparison of value-relevance of accounting information in different segments of the Chinese stock market." International Journal of Accounting 39: 403-427.

Wang, J., and H. Yuan. 2012. "The impact of related party sales by listed Chinese firms on earnings informativeness and earnings forecasts." International Journal of Business 17(3): 258-275.

Weiss, D., P. Naik, and C. Tsai. 2008 "Extracting forward looking information from security prices: a new approach.” Accounting Review 83(4): 1101-1124.

Wu, G., S. Li, and S. Lin. 2014. "The effects of harmonisation and convergence with IFRS on the timeliness of earnings reported under Chinese GAAP". Journal of Contemporary Accounting and Economics 10: 148-159. 


\section{Tables}

Table 1: Sample distribution across industries

\begin{tabular}{lcc}
\hline Industry breakdown & & $\%$ \\
\hline Industry & Number of firms & $4.0 \%$ \\
\hline Mining & 30 & $13.2 \%$ \\
Construction & 98 & $48.5 \%$ \\
Manufacturing & 361 & $12.2 \%$ \\
Transportation \& Public Utilities & 91 & $8.5 \%$ \\
Wholesale Trade & 63 & $6.0 \%$ \\
Retail Trade & 45 & $3.2 \%$ \\
Finance, Insurance, \& Real Estate & 24 & $4.2 \%$ \\
Services & 31 & $0.1 \%$ \\
Public Administration & 1 & $100 \%$
\end{tabular}

Note: Sample of firms that adopt Chinese GAAP and IFRS during 2003-2013. 
Table 2. Summary Statistics relating to variables used in analyses

\begin{tabular}{|c|c|c|c|c|c|c|c|c|c|c|c|c|}
\hline & Overall & 2003 & 2004 & 2005 & 2006 & 2007 & 2008 & 2009 & 2010 & 2011 & 2012 & 2013 \\
\hline \multicolumn{13}{|c|}{ Mean (median) [standard deviation] } \\
\hline \multirow{3}{*}{$\Delta N I_{i, t}$} & 0.004 & 0.004 & -0.001 & -0.018 & 0.017 & 0.059 & -0.042 & 0.001 & 0.028 & 0.029 & -0.026 & 0.004 \\
\hline & $(-0.001)$ & $(-0.000)$ & $(-0.001)$ & $(-0.004)$ & $(0.003)$ & $(0.010)$ & $(-0.017)$ & $(0.002)$ & $(0.004)$ & $(-0.004)$ & $(-0.005)$ & $(0.000)$ \\
\hline & {$[0.393]$} & {$[0.113]$} & {$[0.104]$} & {$[0.088]$} & [0.104] & [0.329] & {$[0.345]$} & {$[0.303]$} & {$[0.375]$} & {$[0.656]$} & {$[0.710]$} & {$[0.628]$} \\
\hline \multirow[t]{3}{*}{$D \Delta N I_{i, t}$} & 0.358 & 0.509 & 0.392 & 0.407 & 0.493 & 0.295 & 0.219 & 0.579 & 0.365 & 0.297 & 0.443 & 0.485 \\
\hline & $(0.000)$ & $(1.000)$ & $(0.000)$ & $(0.000)$ & $(0.000)$ & $(0.000)$ & $(0.000)$ & $(1.000)$ & $(0.000)$ & $(0.000)$ & $(0.000)$ & $(0.000)$ \\
\hline & [0.479] & {$[0.500]$} & [0.489] & [0.492] & {$[0.500]$} & {$[0.456]$} & [0.414] & [0.494] & [0.482] & {$[0.457]$} & [0.497] & {$[0.500]$} \\
\hline \multirow{3}{*}{$D I F R S_{i, t}$} & 0.076 & 0.119 & 0.122 & 0.125 & 0.123 & 0.031 & 0.030 & 0.030 & 0.031 & 0.030 & 0.031 & 0.027 \\
\hline & $(0.000)$ & $(0.000)$ & $(0.000)$ & $(0.000)$ & $(0.000)$ & $(0.000)$ & $(0.000)$ & $(0.000)$ & $(0.000)$ & $(0.000)$ & $(0.000)$ & $(0.000)$ \\
\hline & {$[0.265]$} & {$[0.325]$} & {$[0.328]$} & [0.331] & [0.329] & {$[0.173]$} & [0.169] & [0.169] & {$[0.173]$} & [0.169] & [0.173] & [0.162] \\
\hline \multirow{3}{*}{$S_{i z e} e_{i, t}$} & 21.510 & 21.190 & 21.280 & 21.310 & 21.350 & 21.520 & 21.570 & 21.700 & 21.850 & 22.000 & 22.150 & 22.310 \\
\hline & $(21.380)$ & $(21.100)$ & $(21.160)$ & $(21.230)$ & $(21.320)$ & $(21.470)$ & $(21.500)$ & $(21.670)$ & $(21.800)$ & $(21.920)$ & $(22.020)$ & $(22.160)$ \\
\hline & [1.465] & [1.113] & [1.193] & {$[1.265]$} & [1.390] & [1.507] & {$[1.545]$} & [1.616] & [1.668] & [1.672] & [1.653] & [1.594] \\
\hline \multirow[t]{3}{*}{ Growth $_{i, t}$} & 0.115 & 0.156 & 0.187 & 0.034 & 0.062 & 0.190 & 0.053 & 0.001 & 0.198 & 0.171 & 0.098 & 0.135 \\
\hline & (0.109) & $(0.158)$ & $(0.176)$ & $(0.102)$ & $(0.104)$ & $(0.161)$ & $(0.073)$ & $(0.017)$ & $(0.193)$ & $(0.136)$ & $(0.048)$ & $(0.073)$ \\
\hline & [0.638] & [0.443] & {$[0.525]$} & [0.657] & [0.712] & [0.633] & [0.723] & [0.659] & {$[0.627]$} & {$[0.758]$} & [0.787] & {$[0.570]$} \\
\hline
\end{tabular}


Table 2. Summary Statistics relating to variables used in analyses - Continued

\begin{tabular}{|c|c|c|c|c|c|c|c|c|c|c|c|c|}
\hline & Overall & 2003 & 2004 & 2005 & 2006 & 2007 & 2008 & 2009 & 2010 & 2011 & 2012 & 2013 \\
\hline \multicolumn{13}{|c|}{ Mean (median) [standard deviation] } \\
\hline \multirow[t]{3}{*}{$L e v_{i, t}$} & 2.374 & 1.585 & 1.867 & 2.128 & 1.468 & 3.254 & 2.144 & 2.992 & 2.750 & 1.997 & 2.451 & 3.474 \\
\hline & $(1.215)$ & $(1.118)$ & $(1.196)$ & $(1.304)$ & $(1.313)$ & $(1.257)$ & $(1.300)$ & $(1.323)$ & $(1.377)$ & $(1.354)$ & $(1.482)$ & $(1.523)$ \\
\hline & {$[7.140]$} & [9.601] & {$[12.020]$} & {$[10.520]$} & {$[24.750]$} & [28.240] & [5.342] & {$[20.980]$} & {$[26.013]$} & [5.089] & {$[6.370]$} & {$[13.250]$} \\
\hline \multirow[t]{3}{*}{ Dissue $_{i, t}$} & 0.123 & 0.157 & 0.129 & 0.094 & 0.072 & 0.159 & 0.050 & 0.118 & 0.143 & 0.134 & 0.150 & 0.137 \\
\hline & $(0.089)$ & $(0.129)$ & $(0.092)$ & $(0.072)$ & $(0.064)$ & $(0.108)$ & $(0.043)$ & $(0.096)$ & $(0.133)$ & $(0.089)$ & $(0.083)$ & $(0.082)$ \\
\hline & [0.515] & {$[0.400]$} & {$[0.378]$} & [0.331] & [0.499] & [0.569] & [0.529] & {$[0.542]$} & [0.490] & [0.719] & {$[0.678]$} & [0.518] \\
\hline \multirow[t]{3}{*}{ Turn $_{i, t}$} & 0.647 & 0.577 & 0.635 & 0.664 & 0.743 & 0.714 & 0.720 & 0.638 & 0.690 & 0.727 & 0.679 & 0.663 \\
\hline & $(0.497)$ & $(0.444)$ & $(0.493)$ & $(0.522)$ & $(0.534)$ & $(0.560)$ & $(0.567)$ & $(0.502)$ & $(0.543)$ & $(0.559)$ & $(0.502)$ & $(0.512)$ \\
\hline & [0.713] & {$[0.521]$} & {$[0.556]$} & {$[0.612]$} & {$[1.471]$} & [0.729] & {$[0.712]$} & {$[0.590]$} & {$[0.663]$} & [0.733] & [0.691] & {$[0.688]$} \\
\hline \multirow[t]{3}{*}{$C F_{i, t}$} & 0.046 & 0.041 & 0.055 & 0.050 & 0.023 & 0.048 & 0.118 & 0.048 & 0.016 & 0.012 & 0.033 & 0.027 \\
\hline & $(0.042)$ & $(0.043)$ & $(0.054)$ & $(0.050)$ & $(0.052)$ & $(0.046)$ & $(0.041)$ & $(0.046)$ & $(0.039)$ & $(0.025)$ & $(0.035)$ & $(0.033)$ \\
\hline & {$[0.724]$} & {$[0.090]$} & {$[0.098]$} & {$[0.091]$} & {$[0.924]$} & {$[0.148]$} & [2.307] & {$[0.171]$} & {$[0.455]$} & {$[0.184]$} & {$[0.096]$} & {$[0.184]$} \\
\hline \multirow[t]{3}{*}{$\Delta C F_{i, t}$} & -0.077 & -0.004 & 0.020 & -0.002 & 0.016 & 0.107 & 0.179 & -1.141 & 0.130 & -0.332 & -0.035 & 0.093 \\
\hline & $(0.004)$ & $(0.001)$ & $(0.013)$ & $(0.004)$ & $(0.006)$ & $(0.003)$ & $(-0.000)$ & $(0.007)$ & $(-0.001)$ & $(-0.009)$ & $(0.013)$ & $(0.002)$ \\
\hline & [9.413] & {$[0.148]$} & {$[0.132]$} & [0.114] & {$[0.185]$} & [1.588] & {$[5.576]$} & [31.970] & {$[3.465]$} & {$[8.098]$} & {$[2.560]$} & [1.584] \\
\hline
\end{tabular}

Note: Results reported in this table used a sample of 8,184 firm-year observations. $\Delta N I_{i, t}$ is the change in earnings from year $t-1$ to $t$, scaled by total assets; $D \Delta N I_{i, t-1}$ is a dummy variable equal to 1 if $D \Delta N I_{i, t-1}$ is negative; $\Delta N I_{i, t}$ is the change in earnings scaled by total assets; Size $e_{i, t}$ is the natural logarithm of end of year value of equity; Growt $h_{i, t}$ is the proportionate change in sales; $\operatorname{Lev}_{i, t}$ is the end of year total liabilities divided by end of year equity book value; Dissue $_{i, t}$ is the percentage change in total liabilities; Turn $n_{i, t}$ is sales divided by end of year total assets; and $C F_{i, t}$ is the cash flow from operating activities divided by end of year total assets; $i$ takes values from $1, \ldots, n_{t}$; and $t$ takes values from $2003,2004, \ldots, 2013$. 
Table 3. Conditional Conservatism for all firm-years after controlling for size and industry effects

$\Delta N I_{i, t}=\alpha_{0}+\alpha_{1} D \Delta N I_{i, t-1}+\alpha_{2} \Delta N I_{i, t-1}+\alpha_{3} D \Delta N I_{i, t-1} \times \Delta N I_{i, t-1}+\alpha_{4}$ Size $_{i, t}+\alpha_{5}$ Industry Dummies $_{i, t}+\varepsilon_{t}$

\begin{tabular}{|c|c|c|c|c|c|c|c|c|c|c|c|}
\hline & (1) & (2) & (3) & (4) & $(5)$ & (6) & (7) & $(8)$ & (9) & $(10)$ & (11) \\
\hline & 2003 & 2004 & 2005 & 2006 & 2007 & 2008 & 2009 & 2010 & 2011 & 2012 & 2013 \\
\hline & Pre-reform & Pre- reform & Pre- reform & Pre- reform & Reform & Post- reform & $\begin{array}{l}\text { Post- } \\
\text { reform }\end{array}$ & $\begin{array}{l}\text { Post- } \\
\text { reform }\end{array}$ & $\begin{array}{l}\text { Post- } \\
\text { reform }\end{array}$ & $\begin{array}{l}\text { Post- } \\
\text { reform }\end{array}$ & $\begin{array}{l}\text { Post- } \\
\text { reform }\end{array}$ \\
\hline \multirow[t]{2}{*}{$D \Delta N I_{i, t-l}\left(\alpha_{1}\right)$} & $-0.018^{* * *}$ & $-0.009^{* * *}$ & $-0.016^{*}$ & -0.003 & -0.008 & $0.026^{* *}$ & 0.006 & -0.007 & $-0.013^{* *}$ & -0.005 & -0.008 \\
\hline & $(-3.43)$ & $(-2.73)$ & $(-1.92)$ & $(-0.73)$ & $(-1.10)$ & $(2.19)$ & $(0.88)$ & $(-0.85)$ & $(-2.04)$ & $(-0.97)$ & $(-1.40)$ \\
\hline \multirow[t]{2}{*}{$\Delta N I_{i, t-1}\left(\alpha_{2}\right)$} & -0.056 & $-0.145^{* *}$ & $-0.202^{* * *}$ & -0.059 & $-0.127^{* *}$ & $-0.104^{* * *}$ & $-0.135^{* *}$ & $-0.305^{* * *}$ & $-0.131^{* * *}$ & $-0.231^{* * *}$ & $-0.217^{* * *}$ \\
\hline & $(-0.96)$ & $(-2.00)$ & $(-3.49)$ & $(-0.89)$ & $(-2.13)$ & $(-7.19)$ & $(-2.42)$ & $(-5.74)$ & $(-2.90)$ & $(-4.60)$ & $(-4.31)$ \\
\hline \multirow[t]{2}{*}{$D \Delta N I_{i, t-1} \times \Delta N I_{i, t-1}\left(\alpha_{3}\right)$} & $-0.230^{* *}$ & $-0.184^{* * *}$ & -0.036 & $-0.189^{* * *}$ & $-0.225^{* * *}$ & $-0.283^{* *}$ & $-0.293^{* * *}$ & $-0.309^{* * *}$ & $-0.360^{* * *}$ & $-0.367^{* * *}$ & $-0.378^{* * *}$ \\
\hline & $(-2.42)$ & $(-3.71)$ & $(-0.35)$ & $(-4.67)$ & $(-3.30)$ & $(-2.33)$ & $(-5.37)$ & $(-3.35)$ & $(-4.64)$ & $(-7.09)$ & $(-5.76)$ \\
\hline \multirow[t]{2}{*}{$\operatorname{Size}_{i, t}\left(\alpha_{4}\right)$} & $0.007^{* *}$ & $0.005^{* * *}$ & $0.007^{*}$ & 0.002 & -0.002 & 0.002 & -0.000 & 0.003 & -0.001 & $-0.004^{* *}$ & -0.001 \\
\hline & $(2.39)$ & $(3.50)$ & $(1.89)$ & $(1.26)$ & $(-0.94)$ & $(0.56)$ & $(-0.05)$ & $(0.96)$ & $(-0.53)$ & $(-2.12)$ & $(-0.60)$ \\
\hline \multirow[t]{2}{*}{ Intercept $\left(\alpha_{0}\right)$} & $-0.127^{*}$ & $-0.113^{* * *}$ & -0.159 & -0.043 & 0.061 & -0.039 & 0.006 & -0.060 & 0.041 & $0.134^{* *}$ & 0.016 \\
\hline & $(-1.80)$ & $(-3.15)$ & $(-1.54)$ & $(-0.94)$ & $(0.87)$ & $(-0.34)$ & $(0.08)$ & $(-0.77)$ & $(0.69)$ & $(2.56)$ & $(0.27)$ \\
\hline Industry dummies & YES & YES & YES & YES & YES & YES & YES & YES & YES & YES & YES \\
\hline Adjusted $R^{2}$ & $27.50 \%$ & $8.19 \%$ & $11.80 \%$ & $9.00 \%$ & $6.77 \%$ & $26.30 \%$ & $19.50 \%$ & $26.40 \%$ & $20.30 \%$ & $36.70 \%$ & $22.60 \%$ \\
\hline Number of Obs. & 730 & 733 & 733 & 738 & 740 & 741 & 742 & 742 & 742 & 742 & 742 \\
\hline
\end{tabular}




\section{Table 4. Earnings Smoothness for all firm-years}

Models employed to estimate earnings smoothness:

$\Delta N I_{i, t}=\alpha_{0}+\alpha_{1}$ Size $_{i, t}+\alpha_{2}$ Growth $_{i, t}+\alpha_{3}$ Lev $_{i, t}+\alpha_{4}$ Dissue $_{i, t}+\alpha_{5}$ Turn $_{i, t}+\alpha_{6}$ CF $_{i, t}+\alpha_{5}$ Industry Dummies $_{i, t}+\varepsilon_{i, t}$ $\Delta C F_{i, t}=\alpha_{0}+\alpha_{1}$ Size $_{i, t}+\alpha_{2}$ Growth $_{i, t}+\alpha_{3}$ Lev $_{i, t}+\alpha_{4}$ Dissue $_{i, t}+\alpha_{5}$ Turn $_{i, t}+\alpha_{6}$ CF $_{i, t}+\alpha_{5}$ Industry Dummies $_{i, t}+v_{i, t}$

Comparison of firms' Change in Accounting Quality across time

\begin{tabular}{|c|c|c|c|c|c|c|c|c|c|c|c|}
\hline & (1) & (2) & (3) & (4) & $(5)$ & $(6)$ & (7) & $(8)$ & (9) & $(10)$ & $(11)$ \\
\hline & 2003 & 2004 & 2005 & 2006 & 2007 & 2008 & 2009 & 2010 & 2011 & 2012 & 2013 \\
\hline & $\begin{array}{l}\text { Pre- } \\
\text { reform }\end{array}$ & $\begin{array}{c}\text { Pre- } \\
\text { reform }\end{array}$ & $\begin{array}{c}\text { Pre- } \\
\text { reform }\end{array}$ & $\begin{array}{l}\text { Pre- } \\
\text { reform }\end{array}$ & Reform & $\begin{array}{l}\text { Post- } \\
\text { reform }\end{array}$ & $\begin{array}{l}\text { Post- } \\
\text { reform }\end{array}$ & $\begin{array}{c}\text { Post- } \\
\text { reform }\end{array}$ & $\begin{array}{l}\text { Post- } \\
\text { reform }\end{array}$ & $\begin{array}{c}\text { Post- } \\
\text { reform }\end{array}$ & $\begin{array}{l}\text { Post- } \\
\text { reform }\end{array}$ \\
\hline Variability of $\Delta N I$ & 0.0040 & 0.0033 & 0.0023 & 0.0039 & 0.0046 & 0.0047 & 0.0050 & 0.0053 & 0.0052 & 0.0055 & 0.0055 \\
\hline Mean, SD of Bootstrap Distribn & $\begin{array}{l}0.0047 \\
2.24 E-04\end{array}$ & $\begin{array}{l}0.0034 \\
1.23 E-04\end{array}$ & $\begin{array}{c}0.0023 \\
5.00 E-06\end{array}$ & $\begin{array}{l}0.0039 \\
1.28 E-04\end{array}$ & $\begin{array}{l}0.0047 \\
1.5 E-04\end{array}$ & $\begin{array}{l}0.0050 \\
1.67 E-04\end{array}$ & $\begin{array}{l}0.0058 \\
1.75 E-04\end{array}$ & $\begin{array}{l}0.0059 \\
2.3 E-04\end{array}$ & $\begin{array}{l}0.0054 \\
2.6 E-04\end{array}$ & $\begin{array}{l}0.0060 \\
3.17 E-04\end{array}$ & $\begin{array}{c}0.0058 \\
3.11 E-04\end{array}$ \\
\hline Variability of $\Delta N I$ over $\Delta C F$ & 0.5577 & 0.5244 & 0.3098 & 0.5895 & 0.5852 & 0.4510 & 0.5146 & 0.5816 & 0.5772 & 0.6725 & 0.7747 \\
\hline Mean, SD of Bootstrap Distribn & $\begin{array}{r}0.5579 \\
0.0036\end{array}$ & $\begin{array}{r}0.5247 \\
0.0023\end{array}$ & $\begin{array}{r}0.3092 \\
0.0012\end{array}$ & $\begin{array}{r}0.5893 \\
0.0029\end{array}$ & $\begin{array}{r}0.5857 \\
0.0027\end{array}$ & $\begin{array}{r}0.4510 \\
0.0021\end{array}$ & $\begin{array}{r}0.5145 \\
0.0021\end{array}$ & $\begin{array}{c}0.5818 \\
0.0031\end{array}$ & $\begin{array}{r}0.5773 \\
0.0034\end{array}$ & $\begin{array}{r}0.6729 \\
0.0040\end{array}$ & $\begin{array}{r}0.7745 \\
0.0044\end{array}$ \\
\hline Number of Obs. & 730 & 736 & 738 & 736 & 733 & 731 & 734 & 731 & 733 & 734 & 741 \\
\hline
\end{tabular}

Note: Results reported in this table used a sample of 8,184 firm-year observations. $\Delta N I_{i, t}$ is the change in earnings scaled by total assets; Size is the natural logarithm of end of year value of equity; Growth $h_{i, t}$ is the percentage change in sales; $\operatorname{Lev}_{i, t}$ is the end of year total liabilities divided by end of year equity book value; $D i s s u e_{i, t}$ is the percentage change in total liabilities; Turn $_{i, t}$ is sales divided by end of year total assets; and $C F_{i, t}$ is the cash flow from operating activities divided by end of year total assets; $i$ takes values from $1, \ldots, n_{t}$; and $t$ takes values from $2003,2004, \ldots, 2013$. The variables are winsorized at $5 \%$ level.

$V(\triangle N I) / V(\triangle C F)$ is the ratio of variability of earnings to the variability of cash flows from operating activities, where the variability of earnings is measured by the variance of the residuals from equation 2 and the variability of cash flows is measured by the variance of the residuals from equation 3 . This ratio is to capture the smoothness of earnings related to the smoothness of cash flows. We report the means and standard deviations of the bootstrapped variance of residuals $[V(\triangle N I)]$ and the ratio $[V(\triangle N I) / V(\Delta C F)]$. 
Table 5. Conditional Conservatism for firms follow Chinese GAAP and IFRS after controlling for size and industry effects

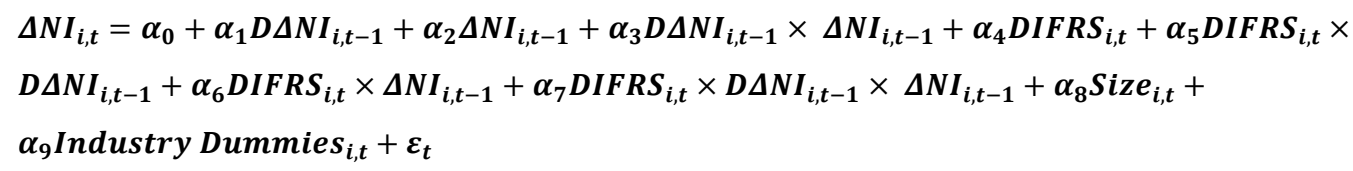

(1)

Pre-reform (2003-2006)

$-0.006^{* * *}$

$(-3.04)$

$-0.181^{* * *}$

$(-6.77)$

$D \Delta N I_{i, t-1} \times \Delta N I_{i, t-1}\left(\alpha_{3}\right)$

$\operatorname{DIFRS} S_{i, t}\left(\alpha_{4}\right)$

$\operatorname{DIFRS}_{i, t} \times D \Delta N I_{i, t-1}\left(\alpha_{5}\right)$

$\operatorname{DIFRS}_{i, t} \times \Delta N I_{i, t-1}\left(\alpha_{6}\right)$

$\operatorname{DIFRS}_{i, t} \times D \Delta N I_{i, t-1} \times \Delta N I_{i, t-1}\left(\alpha_{7}\right)$

$\operatorname{Size}_{i, t}\left(\alpha_{8}\right)$

Intercept $\left(\alpha_{0}\right)$

$(-10.92)$

$0.008^{* *}$

$-0.015^{* * *}$

$-0.034^{*}$

$-0.195^{* *}$

$-0.000$

$(-0.43)$

0.007 (2007-2013)

$-0.013^{* * *}$

0.002

0.014

0.352

0.436

$-0.001$

Chi-Square: $\alpha_{3}(1)=\alpha_{3}(2)$

$7.68 * * *$

0.61

Chi-Square: $\alpha_{3}+\alpha_{7}(1)=\alpha_{3}+\alpha_{7}(2)$

YES

Industry dummies

YES

$19.2 \%$

Adjusted $R^{2}$

$9.13 \%$

2968

2934

Note: Results reported in this used a sample of 8,184 firm-year observations. $\Delta N I_{i, t}$ is the change in income from year $t-1$ to $\mathrm{t}$, scaled by total assets; $D \Delta N I_{i, t-1}$ is a dummy variable equal to 1 if $D \Delta N I_{i, t-1}$ is negative; $i$ takes values from $1, \ldots, n_{t}$; and $t$ takes values from $2003,2004, \ldots, 2013$;

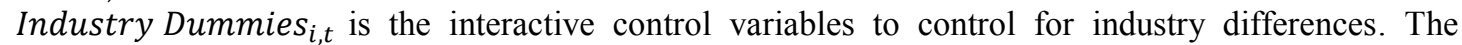
variables are winsorized at $5 \%$ level.

Standard errors are in parentheses. ${ }^{* * * * * *}$, denotes significance at the $1 \%, 5 \%$ and $10 \%$ level, respectively. 
Table 6. Earnings Smoothness for all firm-years for firms follow Chinese GAAP and IFRS

Models employed to estimate earnings smoothness:

$\Delta N I_{i, t}=\alpha_{0}+\alpha_{1}$ Size $_{i, t}+\alpha_{2}$ Growth $_{i, t}+\alpha_{3}$ Lev $_{i, t}+\alpha_{4}$ Dissue $_{i, t}+\alpha_{5}$ Turn $_{i, t}+\alpha_{6}$ CF $_{i, t}+\alpha_{5}$ Industry Dummies $_{i, t}+\varepsilon_{i, t}$

$\Delta C F_{i, t}=\alpha_{0}+\alpha_{1}$ Size $_{i, t}+\alpha_{2}$ Growth $_{i, t}+\alpha_{3}$ Lev $_{i, t}+\alpha_{4}$ Dissue $_{i, t}+\alpha_{5}$ Turn $_{i, t}+\alpha_{6}$ CF $_{i, t}+\alpha_{5}{\text { Industry } \text { Dummies }_{i, t}+v_{i, t}}$

Comparison of firms' Change in Accounting Quality across time and accounting standings

Chinese GAAP

\begin{tabular}{lcc}
\cline { 2 - 2 } & Pre-reform & Post-reform \\
$(2007-2013)$
\end{tabular}

Variability of $\Delta N I$

0.0040

$0.0043,6.73 E-06$

0.0068

$0.0070,1.12 E-04$

0.5882

$0.5883,0.0012$

0.6939

$0.6937,0.0034$

Mean, SD of Bootstrap Distribution

IFRS

\begin{tabular}{cl}
\hline Pre-reform & Post-reform \\
$(2003-2006)$ & $(2007-2013)$ \\
\hline
\end{tabular}

0.0043

0.0012

$0.0040,3.47 E-04$

$0.0013,1.25 E-04$

0.6825

0.5970

3870

4982

$0.6827,0.0039$

$0.5972,0.0071$

Number of Obs.

523

155

Note: Results reported in this table used a sample of 8,184 firm-year observations. $\Delta N I_{i, t}$ is the change in earnings scaled by total assets; Size $_{i, t}$ is the natural logarithm of end of year value of equity; Growt $h_{i, t}$ is the percentage change in sales; $L e v_{i, t}$ is the end of year total liabilities divided by end of year equity book value; Dissue $e_{i, t}$ is the percentage change in total liabilities; Turn $_{i, t}$ is sales divided by end of year total assets; and $C F_{i, t}$ is the cash flow from operating activities divided by end of year total assets; $i$ takes values from $1, \ldots, n_{t}$; and $t$ takes values from 2003, 2004, ., 2013. The variables are winsorized at 5\% level.

$V(\Delta N I) / V(\triangle C F)$ is the ratio of variability of earnings to the variability of cash flows from operating activities, where the variability of earnings is measured by the variance of the residuals from equation 2 and the variability of cash flows is measured by the variance of the residuals from equation 3 . This ratio is to capture the smoothness of earnings related to the smoothness of cash flows. We report the means and standard deviations of the bootstrapped variance of residuals $[V(\Delta N I)]$ and the ratio $[V(\Delta N I) /$ $V(\triangle C F)]$. 